\title{
Skeletal Muscle Tissue Engineering Using Biological Scaffolds for Repair of Abdominal Wall Defects in a Rabbit Model
}

\author{
Zuki Abu Bakar ${ }^{1}$, Ayele Taddese Tsedeke ${ }^{2}$, \\ Noorjahan Banu Mohamed Alitheen ${ }^{3}$ and Noordin Mohamed Mustapha ${ }^{1}$ \\ ${ }^{1}$ Faculty of Veterinary Medicine, Universiti Putra Malaysia, Malaysia \\ ${ }^{2}$ Faculty of Veterinary Medicine, University of Gondar, \\ ${ }^{3}$ Faculty of Biotechnology and Biomolecular Science, Universiti Putra Malaysia \\ 1,3Malaysia \\ ${ }^{2}$ Ethiopia
}

\section{Introduction}

The repair of large soft tissue defects, especially abdominal wall defects, is still a challenge for surgeons and continues to be a significant problem for patients (Gangwar et al., 2006; Lai et al., 2003). Free muscle transfer from local or distant sites is commonly employed for the surgical repair of muscle-tissue defects, but this practice is frequently associated with significant donor-site morbidity (Wei et al., 1995). A potential alternative includes the in vitro development of a functional three-dimensional muscle for transplantation or the construction of implantable biological biomaterials to direct myogenesis at the target site. The ideal biomaterial for abdominal wall repair should possess adequate strength, no hypersensitivity reactions, and biocompatibility to facilitate tissue ingrowths, which may help long-term maintenance of mechanical strength (Lai et al., 2003). In the reconstruction of a new tissue, two components are usually very important: the cells and the matrix (scaffolds) where they are seeded.

Tissue engineering is an interdisciplinary field which applies the principles and methods of engineering and the life sciences towards the fundamental understanding of structural and functional relationships in normal and pathological tissue and the development of biological substitutes to restore, maintain or improve function (Skalak \& Fox, 1988). The creation of skeletal muscle tissue using tissue engineering methods holds promise for the treatment of a variety of muscle diseases, including skeletal myopathies such as muscular dystrophy or spinal muscular atrophy, traumatic injury and aggressive tumor ablation (Guettier-Sigrist et al., 1998; Law et al., 1993). Tissues that are engineered using the patient's own cells, or immunologically inactive allogenic or xenogenic cells have the potential to overcome current problems of replacing lost tissue function and offer new therapeutic options for diseases where currently no options are available. Moreover, this technology can play a vital role in the future management of paediatrics patients (Saxena et al., 1999a). 
In general "Tissue engineering" refers to the science of creating living tissue to replace, repair or augment diseased tissue. The engineered tissue may be created in vitro and subsequently implanted into the patient or the tissue may be created entirely in vivo. Regardless of the technique, tissue engineering requires at least three components: a growth-inducing stimulus (induction), responsive cells (production), and a scaffold (biomaterials) to support tissue formation (Bronzino, 2006).

Biomaterials are any material used to make devices to replace a part or a function of the body in a safe, reliable, economic and physiologically acceptable manner (Hench \& Erthridge, 1982). The use of biomaterial for repair of abdominal wall defects is gaining increasing recognition and the use of biomaterials to achieve a tension-free repair has resulted in a significant reduction in post-operative pain, length of recovery period and the number of recurrence (Amid, 1997).

Currently there is an increasing demand for cheap and ideal biomaterials which can be used in reconstructive surgery for repair of traumatic wounds suffer during war, traffic accidental and natural disaster and in the restore of the functions of diseased tissues or organs. Biomaterials are either synthetic (prosthesis) such as ceramic, polymeric and composite or biologic (bioprosthesis) such as heart valve, skin and other types of tissue graft (Black, 1992). The ideal biomaterials for abdominal wall repair should possess adequate strength, no hypersensitivity reactions and biocompatibility to facilitate tissue ingrowths, which may help long term maintenance of mechanical strength (Lai et al., 2003).

Recently, new biodegradable biomaterials developed from biological materials mainly of collagen in nature have been tested for repair of body wall instead of the non-biodegradable synthetic materials. Bovine pericardium, human cadaveric fascia lata, human dura mater and collagen-based materials derived from porcine small intestine submucosa have been investigated for reconstruction of abdominal wall defects (Ueno et al., 2004; Saaverda et al., 2001; Santillan et al. 1995; Rodgers et al., 1981). However in most research, it is indicated that these collagen based biomaterials are failed to be replaced by skeletal muscle tissue or regeneration of muscle tissue is not observed as whole therefore optimal muscle recovery or regeneration may require the use of novel technology like tissue engineering. Skeletal muscle comprises approximately $48 \%$ of the body mass and is responsible for voluntary control and active movement of the body. Application of tissue engineering techniques and successful fabrication of skeletal muscle mass holds now a promising future for the restoration of 3-dimentional contour as well as the loss of function for the affected part of the body. In order to generate skeletal muscle tissue, myoblasts which are skeletal muscle tissue precursors, have been employed (Saxena, 2005).

One of the strategies for muscle tissue engineering involves the harvesting of satellite cells, their expansion in vitro, and their subsequent autologous implantation in vivo into the sites requiring repair or replacement. One of the main obstacles in the formation of new muscle tissue is the lack of an adequate support for expanded satellite cells. To overcome this obstacle, many researcher groups are trying to develop adequate synthetic and biological delivery systems for implanted cells (Conconi et al., 2005). Currently myoblast transplantations have been predominantly performed by injection of myoblast cell suspensions into mature skeletal muscle. These single cells have been shown to fuse with the host myofibers (Wernig et al., 2000). Saxena et al. (1999b) were the first to implant successfully in vitro cultured myoblasts into a non-muscular environment. Their group used a polyglycolic acid (PGA) mesh as a scaffold for skeletal muscle cells (Saxena et al., 2001; 
Saxena et al., 1999b). Myoblasts have also been seeded onto polyglycolic acid porous polymers with successful generation of vascularized new skeletal muscle in vivo (Saxena and Willital, 2000). Synthetic materials, such as Dacron and Polytetrafluorethylene, have been used to repair congenital muscles defects, e.g. Onfalocele and gastrochisis (Bauer et al., 1999; Calzolari et al., 1995; Meddings et al., 1993). However, all of these materials do not allow cell growth and do not follow host development. Evidence has been provided that biological materials can support in vivo and in vitro cell adhesion and proliferation.

Bovine pericardium has been used as source of natural biomaterials for a wide range of clinical applications (Jose et al., 2001; Won et al., 2000; Marques et al., 1995). However, few clinical data are available in current literature about grafting of bovine tunica vaginalis parietalis for surgical use, although up to $10 \times 7 \mathrm{~cm}$ or larger collagen rich sheet of tunica vaginalis parietalis can be obtained from a testis of adult cattle. Naturally derived materials, including glutaraldehyde tanned bovine pericardium (James et al., 1991), small intestine submucosa (Clarke et al., 1996; Prevel et al., 1995) and also lyophilized and glycerolized bovine pericardium and tunica vaghinalis parietalis (Hafeez, 2005), have been tried in animal models. These biomaterials are less susceptible to infection and cause less foreign body response (Badylak et al., 1998; Hiles et al., 1995). Thus, the utilization of non-edible bovine offal's of collagenous nature for the development of cheap and safe surgical patches for clinical use will be of economical importance in developing countries. However, fail to recover muscle tissue and also lack of strength over time is a concern for clinical application in which adequate tensile properties are necessary. Thus, for this reason, it is important to understand not only the biological response to degradable biomaterials, but also the expected mechanical properties of implant and replacement of tissue over time. These new collagen based biomaterials has to be improved its morphological and biomechanical properties just by seeding it with myoblast cells and must be evaluated first in animals' model before being approved for test in human.

In this study, biological collagen-based biomaterials were employed for reconstruction of abdominal wall defects in a rabbit model. These are bovine parietal pericardium and bovine tunica vaginalis parietalis which were collected from abattoir and processed by freezedrying preservation methods and sterilized using gamma irradiations system. In recent years, this preservation method in combination with sterilization using gamma irradiation has been reported in its good output (Zuki et al., 2007; Hafeez, 2005; Hafeez et al., 2005a, 2005b).

A reason for future use of collagen-based biomaterials seems functioning as temporary scaffolds which during resorption generate new permanent tissue. However, very fast resorption rates were reported for degradable materials of synthetic or natural origin (Smith et al., 1989; Tyrell et al., 1989). Moreover, fail to recover muscle tissue and also lack of strength over time is a concern for clinical application in which adequate tensile properties are necessary.

\section{Morphological evaluation of the myoblast seeded scaffolds in vitro}

The parietal pericardial sacs and tunica vaginalis parietalis were collected from healthy adult cattle immediately after slaughter, placed in polyethylene plastic bags containing cold normal saline and transferred into an icebox for transportation. The BP and BTV sacs were cleaned, trimmed into rectangular sheets and washed thoroughly under running tap water 
and rinsed in serial changes of sterile saline (Figure 1). The BP and BTV sheets were then transferred aseptically into a sterile bottle containing $150 \mathrm{ml}$ of $0.05 \%$ sodium hypochlorite and shaken slowly for 10 minutes. The sodium hypochlorite were then washed off by shaking the tissue sheets in three changes of sterile normal saline for 20 minutes each change, then kept overnight at $4{ }^{\circ} \mathrm{C}$. The BP and BTV sheets were freeze-dried and sterilized by gamma irradiation at 25 KGy (Cobalt 60, JS8900, IR-174; CDM MDS NORDION, Ontario, Canada) according to the MINT (Malaysian Institute for Nuclear Technology) tissue bank work instruction Manual (1998) (Figure 2). Samples were taken from both BP and BTV grafts for histological and SEM examinations. The sections were stained with Haematoxylin and Eosin as described by Wilson and Gamble, (2002) for general histology and Masson's trichrome method as described by Jones, (2002) for demonstration of muscles and collagenous tissue.

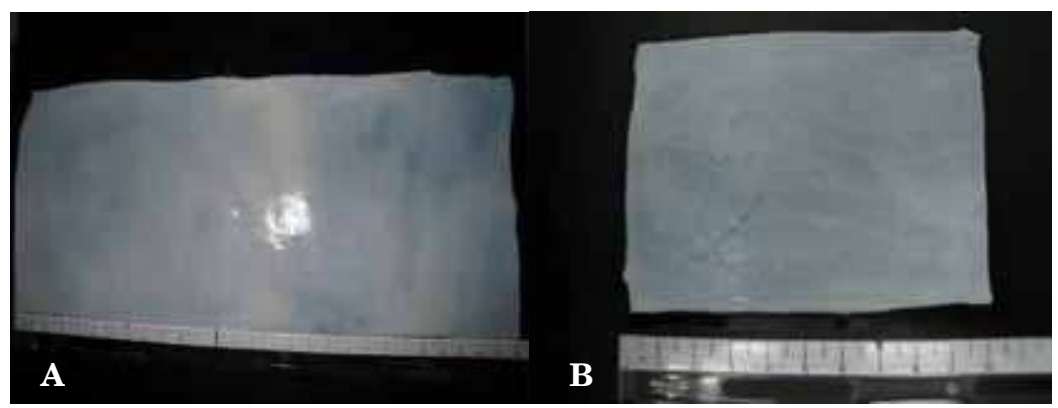

Fig. 1. Photographs A and B show BP and BTV after cleaning, respectively

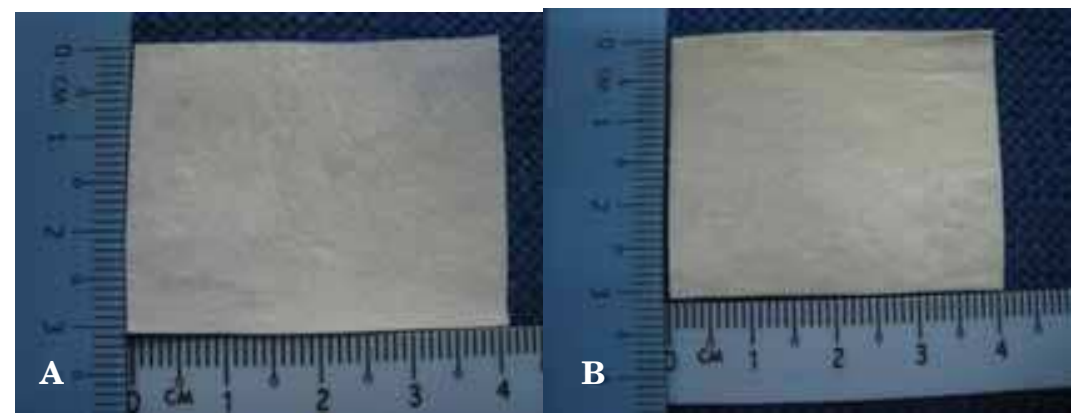

Fig. 2. Photographs A and B show $3 \times 4 \mathrm{~cm}^{2}$ scaffolds derived from BP and BTV, respectively. Note both have similar appearance macroscopically

Biomaterials provide mechanical stability to the construct in the short term and serve as a template for the three-dimensional organization for the developing tissue (Hutmacher, 2001). Therefore a critical step in skeletal muscle-tissue engineering is the identification of the optimal biomaterial scaffold, able to promote normal differentiation and maturation of myoblasts into myotubes and myofibers. At present, several kinds of natural scaffolds, such as porcine small intestinal submucosa (Badylak et al., 2002), acellular dermal matrix (Chung et al., 2003) and collagen (Lai et al., 2003) have been employed to repair 
abdominal wall defects in experimental animal models. Acellular matrices, obtained by detergent-enzymatic method do not elicit rejection responses (Roeder et al., 1999) and could be employed as promising tissue substitutes (Parnigotto et al., 2000a, 2000b; Sutherland et al., 1996).

\subsection{Light and scanning electron microscopic evaluations of the scaffolds}

Bovine parietal pericardium and bovine tunica vaginalis parietalis were used to obtain a biological scaffold possessing morphological and mechanical properties resembling those of the native tissue. Bovine pericardium originated scaffolds seems have large pores and less interconnectivity with completely acellular (Figure 3A) and is collagenous-based in nature with no cellular and vascular element (Figure 4A), and this might be as a result of slight modification of preparation methods used in the previously reported methods by Hafeez, (2005) in conjunctions with light density of collagen as compared with BTV. However, BTV originated scaffolds possessing large pores and less interconnectivity with scanty cell remnant within dense collagen bundles (Figures 3B and 4B), and this perhaps contributed by high density of the structural fiber components. A similar result has been reported by Hafeez, (2005). The light and electron microscopic examinations revealed that nearly all cellular components were removed without ultrastructural evidence of damage to fibrous components. Even though similar acellular results were obtained by Chang et al. (2002) in their in vivo evaluation of cellular and acellular bovine pericardia fixed with a naturally occurring crosslinking agent (genipin). But, they had used a special cell extracting methods which was not used in this study.

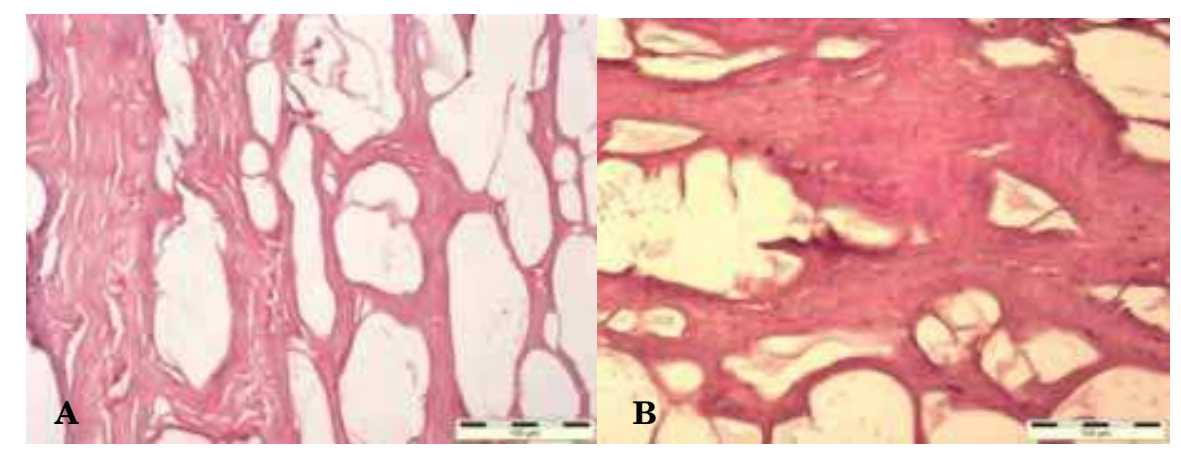

Fig. 3. Microphotographs of the collagen based of BP (A) and BTV (B) scaffolds show the pore size appears larger with less interconnectivity. Note also the scanty remnant cellular elements within a dense connective tissue matrix in $\mathrm{B} . \mathrm{H} \& \mathrm{E}$, Bar $=100 \mu$

Scanning electron microscopic examinations revealed that the serosal/inner surface of both type of scaffolds (BP and BTV scaffolds) had irregular polygonal shape structure (Figures $5 \mathrm{~A}$ and $6 \mathrm{~A})$. However, the outer layers were rough with irregular appearance of connective tissue (Figures $5 \mathrm{~B}$ and $6 \mathrm{~B}$ ). The finding of this study is in accordance to the result reported by Hafeez (2005). They had reported that the surface of freeze-dried BP and BTV differ from fresh BP and BTV in many aspects such as the lost of the serosal layer and the exposure of underlying collagen bundles and separation of individual collagen bundles, and fibers, which appeared to be wavy and well defined. Adequate porosity with interconnected pores 
is required not only to achieve sufficient cell seeding density within the scaffold, but also to facilitate cell proliferation and differentiation by allowing the transport of nutrients and oxygen into and out of the scaffold (Goddard \& Hotchkiss, 2007). This study has also demonstrated that the processed collagen-based biomaterials such as BP and BTV are sufficiently porous in nature (Figure 7). A similar result had been reported on bovine parietal pericardium (Chang et al., 2005).

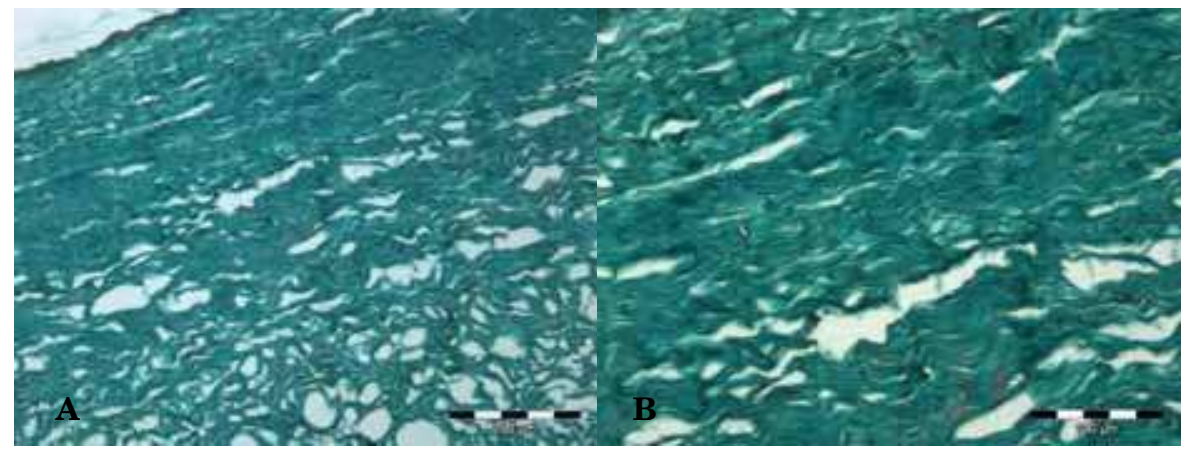

Fig. 4. Microphotographs of the masson's trichrome stained BP (A) and BTV (B) scaffolds show the scaffold is collagenous-based in nature with no cellular and vascular element in A, and dense collagenous tissue with scanty cellular elements in B. Bar $=100 \mu$

Based on the light and scanning electron microscopic analysis the prepared pre-implanted BP and BTV are fibro-collagenous in nature with no or very few cellular remnants which make this biomaterials weak antigenicity apart from its excellent biocompatibility and biodegradability. This is a fascinating result to address the need of non-immunogenic and non-prosthetic biomaterials that could guide perhaps the regeneration of normal tissue. This study has also revealed that processed BP and BTV are porous in nature that could achieve to accommodate sufficient cell seeding density and facilitate cell proliferation and differentiation by allowing the transport of nutrient and oxygen into and out of the scaffolds (Goddard \& Hotchkiss, 2007).

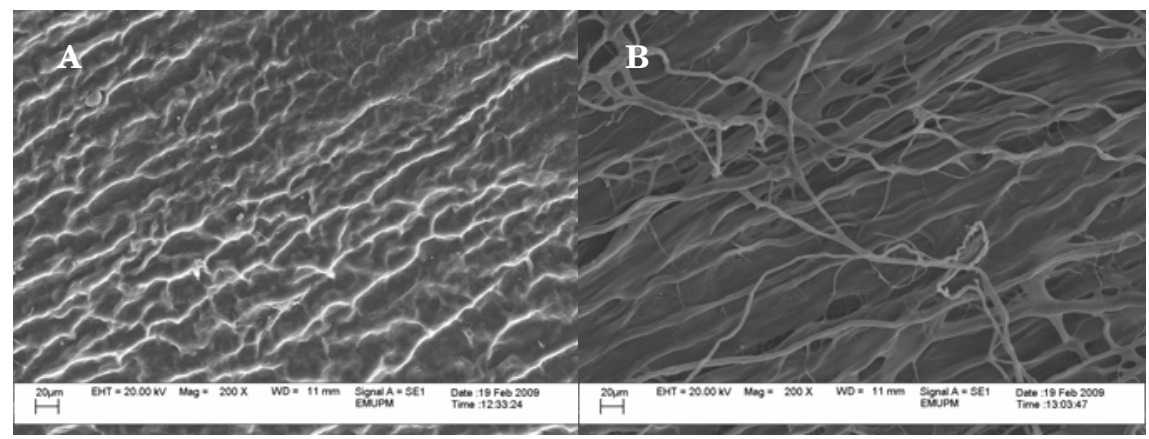

Fig. 5. SEM electronmicrographs of the A) serosal/interior and B) epipericardial surfaces of BP scaffold showing polygonal shape structure and irregular fibrous surface, respectively 


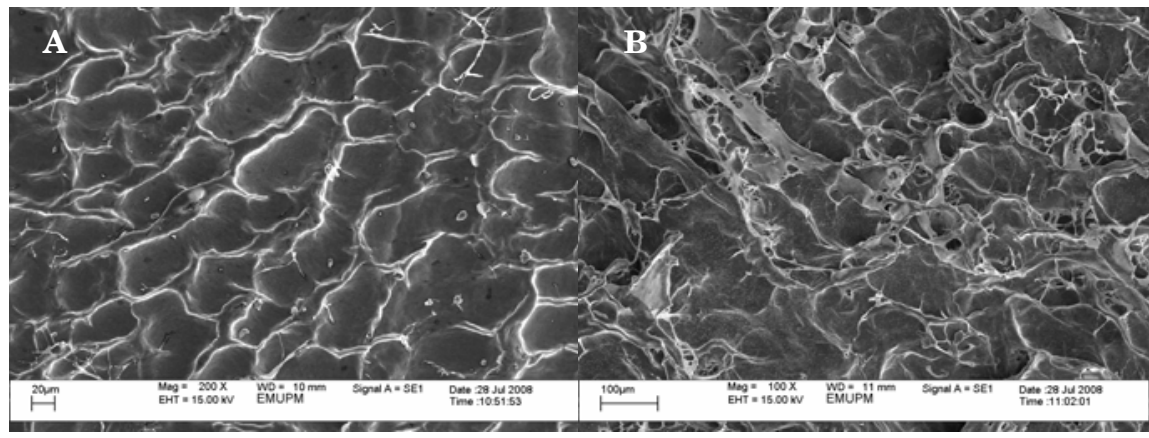

Fig. 6. SEM electronmicrograph of the A) serosal and B) scrotal surfaces of BTV scaffold showing polygonal shape structures and irregular surface, respectively

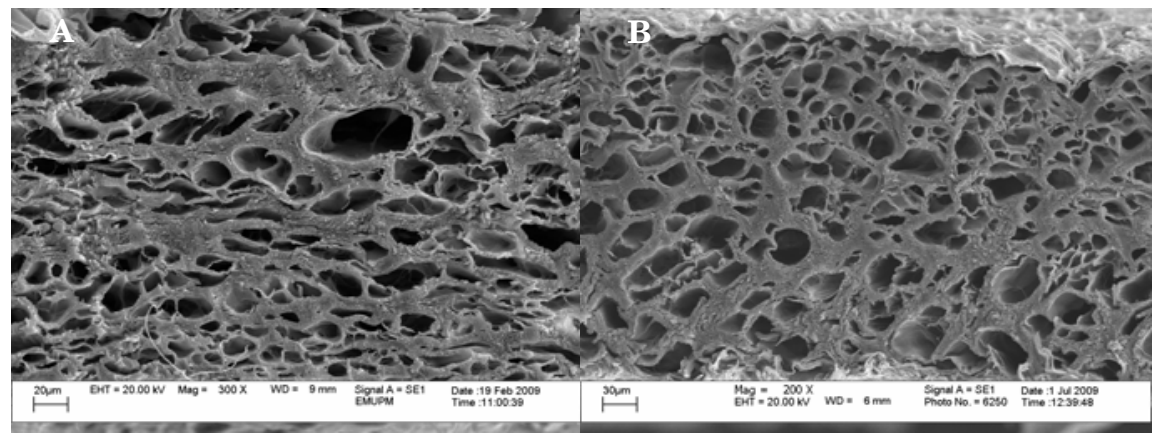

Fig. 7. SEM electronmicrographs of the cross sectioned scaffolds of BP (A) and BTV (B) showing good porosity

\subsection{Skeletal myoblast harvesting and isolation analysis}

Skeletal muscle tissue engineering depends on the unique regenerative properties of satellite cells and the ability to direct intrinsic cell programs associated with proliferation and differentiation. The development of muscle stem cells and genetically engineered myoblasts for transplantation has become in the past few years a very attractive and challenging method for treatment of patients with muscle diseases (Wu et al., 2003; Huard et al., 2003; Haider et al., 2003). However, the repair of extensive muscular defects or diseased regions may require voluminous tissue grafts seeded with large amounts of myoblasts.

Skeletal muscle tissues were obtained from the hind limbs muscle (Soleus muscles) of 5-dayold rabbit using a primary cell culture. Cell purity is assessed by desmin antibodies to prove the purity of the cultured myoblast using immunocytochemistry analysis and also quantified by flow cytometric analysis. This identification method has been also employed by many researchers despite their slight variation in techniques (Guarita-Souza et al., 2006; Ott et al., 2004; Lai et al., 2003; Winokur et al., 2003; Rando \& Blau, 1994). The prepared $3 \times 4$ $\mathrm{cm}^{2}$ scaffolds were seeded with myoblast at a density of $1.0 \times 10^{7}$ cells. Cell morphology and growth in the scaffolds were examined using SEM. 
During the initial stages of culture, the myoblast showed a rounded morphology. After the first 24 hours, the cells attached to the culture surfaces and also spindle-shaped cells started to sprout out from isolated muscle fibres and then proliferated. Therefore, this work allowed us to obtain muscle satellite cell-derived cultures, containing myoblasts, expressing the transcription factors involved in the skeletal muscle-cell differentiation program (Chen \& Goldhamer, 2003). Moreover, cultured myoblasts are endowed with a high proliferation rate, so that only three weeks is needed to reach the optimal cell number for graft implantation. Hence, this myoblast isolation technique appears to give a better result than those previously used to isolate satellite cells by Lai et al. (2003), Marzaro et al. (2002) and Van Wachem et al. (1999), but it appears to give a similar results reported by Conconi et al. (2005).

Moreover the culture technique that has been used allows the preferential growth of myoblasts over fibroblasts, and the yield of myogenic cells from the initial primary culture is very high and hence the percentage of myogenic cells increases with time in culture. Thus, from a mixed culture of myoblasts and fibroblasts, a nearly pure culture of myoblasts were achieved within three weeks and therefore the purity of the myoblast was confirmed using desmin immunocytochemistry which is a common preferable method employed by many researchers to produce a better result (Guarita-Souza et al., 2006; Conconi et al., 2005; Kamelger et al., 2004). Myoblast percentages were determined using flow cytometric analysis. According to desmin immunocytochemistry and flow cytometric analysis more than $97 \%$ of the isolated skeletal myoblast cells have got myogenic phenotype (Figures 8). However, Lai et al. (2003) had reported that approximately $80 \%$ of isolated skeletal muscle cells had a myogenic phenotype in desmin immunocytochemistry analysis which perhaps indicates the superiority of the present technique to isolate myoblast.

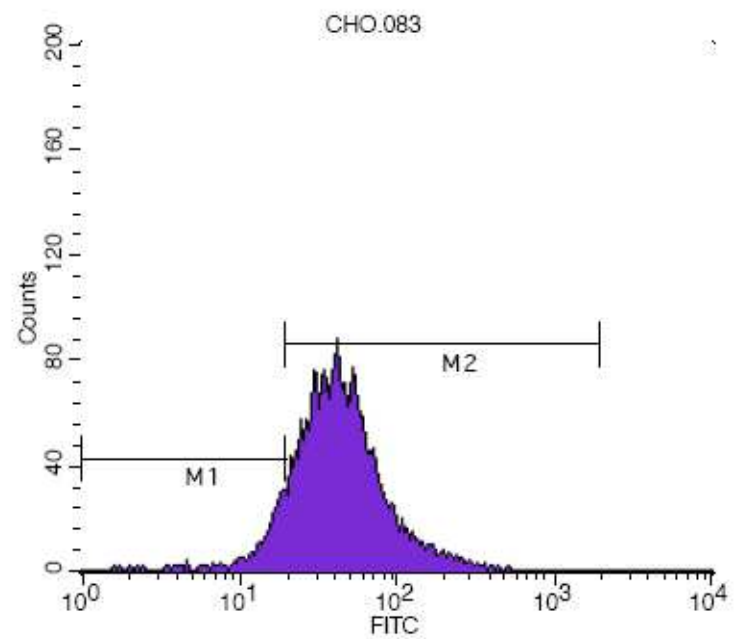

Fig. 8. Flow cytometric histograms depicted FITC-conjugated desmin positive myoblast. Note that the percentage of pure myoblast is $97 \%$ whereas non myoblast cells are $3 \%$ in flow cytometry analysis. M1= Proportion of desmin negative cells, M2= Proportion of desmin positive cells 
In vitro test revealed the ability of myoblast to form myotube in static culture on the surface of petri-dish which was not even a tissue culture flask. However, there were only few cells on the surface with haphazard arrangement which is perhaps related to the adhesion properties of the cell towards the petri-dish as showed in figure 9. This result is in agreement with Yan et al. (2006) who reported that if the myoblast cells are plated on plain plastic tissue culture or on non-aligned collagen gels, the satellite cells differentiate into skeletal myotube but the arrangement is haphazard.

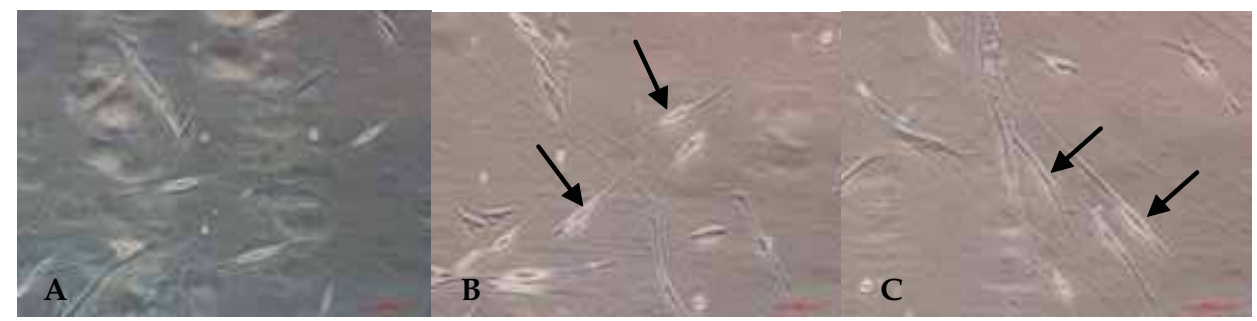

Fig. 9. The phase-contrast microphotographs showing A) the spindle-shaped myoblast at 24 hrs post-seeding, B) long spindle-shaped myoblast at $72 \mathrm{hrs}$ post-seeding with some multinucleated myotube (arrows) and C) long spindle-shaped myoblast and myotube at 120 hrs post-seeding with some multinucleated myotube (arrows). Bar $=100 \mu$

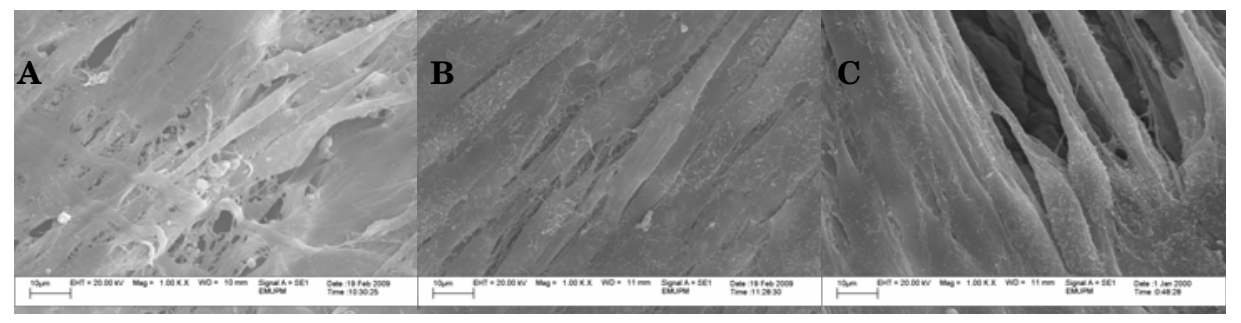

Fig. 10. SEM electronmicrographs of the myoblast seeded bovine pericardium scaffold at A) $24 \mathrm{hrs}, \mathrm{B}) 72 \mathrm{hrs}$ and C) $120 \mathrm{hrs}$ post-seeding. Note the myoblast covering almost the entire surface of the scaffolds (A), the unidirectional pattern of myotube (B) and the fusion of myotubes to form myofibres (C)

The SEM examinations revealed that both type of BP and BTV scaffolds were able to support myoblast growth and differentiation, which were evidenced by few myoblast began to cover the whole surface of the scaffolds and fused into myotube within $24 \mathrm{hrs}$ (Figure 10A). At the $3^{\text {rd }}$ and $5^{\text {th }}$ day post-seeding, the myoblast continues to fuse and form a series of uniformly arrayed myotube (Figure 10B), whereas at $5^{\text {th }}$ day post-seeding densely packed myotube with morphology reflecting myofibers were also observed (Figure 10C), and these results found to be almost consistent with result reported by Yan et al. (2006), where their study focused on tissue engineering of skeletal muscle using aligned collagen gel coated tissue flask. A similar result had been also reported by Conconi et al. (2005) on the homologous muscle acellular matrix seeded with autologous myoblasts as a tissue-engineering approach to abdominal wall-defect repair. A critical step in skeletal muscle-tissue engineering is the 
identification of the optimal biomaterial scaffold, able to promote normal differentiation and maturation of myoblasts into myotubes and myofibers (Conconi et al., 2005). In this work, biologically originated collagen-based biomaterials were used to obtain a scaffold possessing morphological and mechanical properties resembling those of the native tissue, and in vitro findings confirmed that this matrix is able to support myoblast growth and differentiation.

\section{Post-implantation evaluations of myoblast seeded scaffolds}

In this study we used a total of 36 rabbit which were randomly divided into four experimental groups (Group I, II, III and IV), comprising of equal number of animals. Group I and II served as the treatment groups, while the other groups acted as control. Three rabbits from each group were randomly selected and scarified using an intra-cardial injection of sodium pentobarbital (CEVA, Sante animale, France) at a rate of $100 \mathrm{mg} / \mathrm{kg}$ at $7^{\text {th }}, 14^{\text {th }}$ and $30^{\text {th }}$ day post implantation as described in Table 1.

\begin{tabular}{cccccc}
\hline & & \multicolumn{3}{c}{ Scarifying date } & \\
\cline { 3 - 5 } & & $7^{\text {th }}$ Day & $14^{\text {th Day }}$ & 30 & \\
\hline \multirow{2}{*}{ Treatment Day } & No of rabbits \\
\hline \multirow{2}{*}{ Control Groups } & Group I & 3 & 3 & 3 & 9 \\
& Group II & 3 & 3 & 3 & 9 \\
\hline & Group III & 3 & 3 & 3 & 9 \\
& Group IV & 3 & 3 & 3 & 9 \\
\hline & & 12 & 12 & 12 & 36
\end{tabular}

Group I -Myoblast seeded BP scaffolds

Group II -Myoblast seeded BTV scaffolds

Group III -Non-Seeded BP scaffolds

Group IV -Non-Seeded BTV scaffolds

Table 1. Experimental Design

\subsection{Post-operative care and follow up analysis}

The animals tolerate well to the surgical procedure and none of the rabbits died during surgical process with no post-implantation mortality which may be due to satisfactory anaesthetic technique (Table 2). Dullness, depression and partial anorexia in the immediate postoperative period was attributed to surgical trauma and inflammation at the site of reconstruction. A similar result was reported by Gangwar et al. (2006) using acellular dermal graft for repair of abdominal wall defects in rabbits. Neither the treatment groups nor its control groups in both types of scaffolds have showed any wound complication and infection as shown in figure 11, since, the complication rate after repair of large tissue defects strongly depends on applied reconstructive material. Wound infections, bowel fistulae, and repair failures can occur when synthetic materials were used for defect closure. However, naturally derived materials are less susceptible to infection (Drewa et al., 2005; Schlatter et al., 2003; Dolgin et al., 2000; Minkes, et al., 2000). 


\begin{tabular}{ccccc}
\hline Groups & $\begin{array}{c}\text { No. of } \\
\text { Rabbit }\end{array}$ & $\begin{array}{c}\text { No. of } \\
\text { mortality (\%) }\end{array}$ & $\begin{array}{c}\text { No. of } \\
\text { Adhesion (\%) }\end{array}$ & $\begin{array}{c}\text { No. of } \\
\text { Seroma (\%) }\end{array}$ \\
\hline Group I & 9 & $0(0)$ & $1(11.11)$ & $0(0)$ \\
Group II & 9 & $0(0)$ & $0(0)$ & $0(0)$ \\
Group III & 9 & $0(0)$ & $3(33.33)$ & $0(0)$ \\
Group IV & 9 & $0(0)$ & $2(22.22)$ & $1(11.11)$ \\
\hline
\end{tabular}

Table 2. Post-operative complications

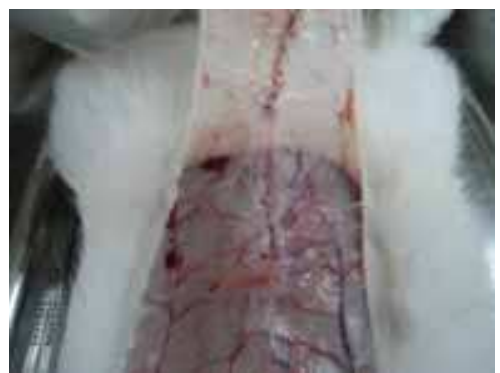

Fig. 11. Subcutaneous surface of the implanted scaffolds is covered by new/old fascia originated from surrounding fascia with overwhelming blood vessels in Group I on day 7 post-implantation

\subsection{Macroscopic analysis}

The vascular change at reconstructive site is a part of normal body response to injury. It is an attempt to increase resorption and removal of clot and debris from the wound site and finally helping in the laying down of fibrous tissue (Silver, 1982). Therefore, the present results revealed the increased vascularity at the reconstructive site in all groups of rabbit in both type of scaffolds as the post-operative day advances. Although variable degree of angiogenesis were a common feature of the treatment and its control groups in both $\mathrm{BP}$ and BTV scaffolds, and hence overwhelming neo-angiogenesis were recorded in the treatment groups of both type of scaffolds which might be attributed by seeding of myoblast on the scaffolds.

The study has showed that deposition of loose fibrous connective tissue and white connective tissue was observed in all the groups of rabbit regardless of the scaffolds type. However, it was on groups I and II complete neo-peritoniazation began with the appearance of glistening membrane covering the inner surface of the graft at day $7^{\text {th }}$ of postimplantation (Figure 12) which is indeed earlier than the study conducted by Singh et al. (2008) in acellular biomaterials of porcine origin for the reconstruction of abdominal wall defects in rabbits, where complete peritoniazation the graft occurred at $21^{\text {st }}$ post-operative day, and their finding relatively similar with the control groups of our study where early peritoniazation on the implanted scaffolds was not observed in the control groups in which myoblast was not seeded. Therefore myoblast seeding might be a good justification for early peritoniazation. 


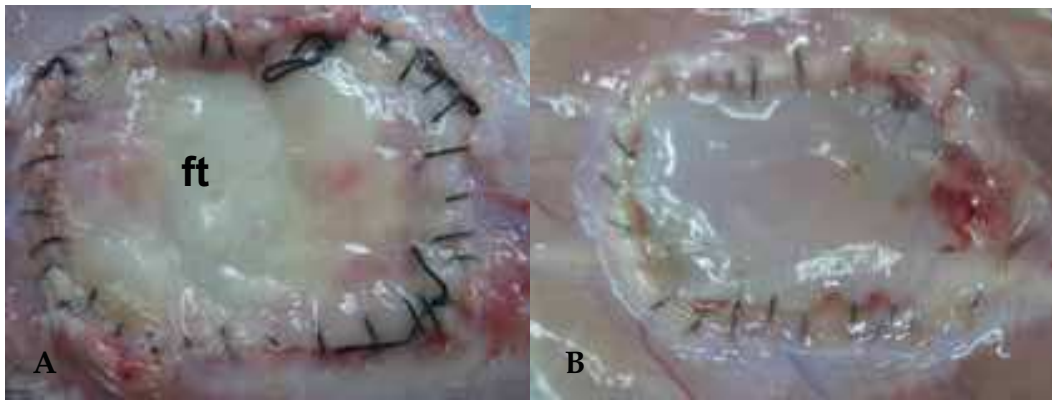

Fig. 12. Peritoneal surface of the implanted graft in Group I (A) and group II (B) on day 7 post implantation showing the surface is completely covered by newly formed white fibrous tissue including the fatty tissue $(\mathrm{ft}$ ) and neo-peritoneum that appears smooth and shinny

Naturally derived materials, including glutaraldehyde tanned BP (James et al., 1991), small intestine submucosa (Clarke et al., 1996; Prevel et al., 1995) and also lyophilized and glycerolized BP and BTV (Hafeez, 2005), have been tried in animal models. These biomaterials are less susceptible to infection and cause less foreign body response (Badylak et al., 1998; Hiles et al., 1995). However, fail to recover muscle tissue and also lack of strength over time is a concern for clinical application. Macroscopically, at day $30^{\text {th }}$ of postimplantation, our study revealed that the control groups III and IV have showed thinning and fascial weakness, which was evidenced by pouching and distension appearance of the abdominal wall as shown in Figure 13.

Lai et al. (2003) had proven that scaffolds covered with cells had better mechanical properties than acellular/non-seeded scaffolds in body wall repair using small intestinal submucosa seeded with cells. Fauza et al. (2001) had also reported acellular collagen-based matrix alone may be insufficient scaffold for abdominal wall reconstruction. However, in our study none of the treatment groups, in both types of scaffolds have showed pouching and distension appearance of the abdominal wall, rather various degree of tissue regeneration was noticed, which was evidenced by graft opacity, and overwhelming blood vessels, fatty tissues, fibrous tissue and neo-peritoneum was observed in myoblast seeded groups of both type of scaffolds at 30 days of post-implantation (Figure 14).

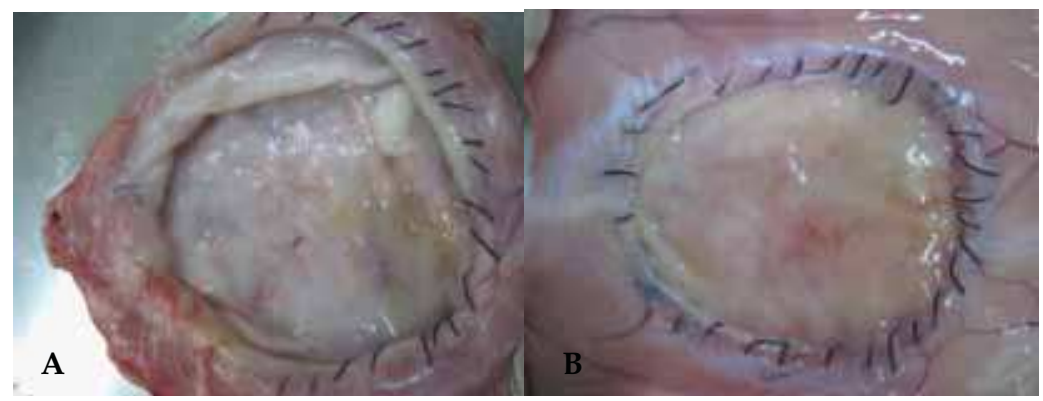

Fig. 13. Peritoneal surface of the implanted graft in group III (A) and group IV (B) on day 30 post-implantation showing the implanted graft over-stretched and lead to pouching appearances with very few blood vessels 


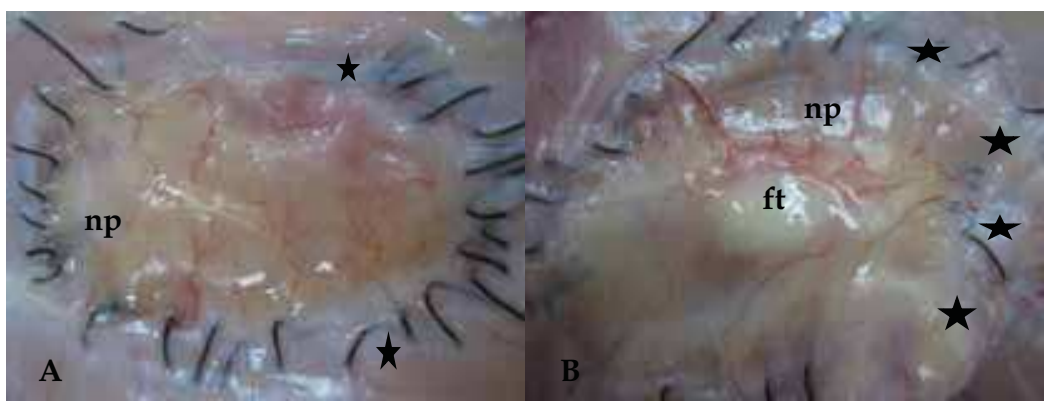

Fig. 14. Peritoneal surface of the implanted graft in group I (A) and group II (B) on day 30 post-implantation showing the neo-peritoneum (np) covered all over the surface with numerous blood vessels and white fibrous tissue at host-graft junction (stars), fatty tissue (ft)

In this study, the wound strength of repair was not evaluated. However, the firm integration was observed between the implant and host tissue produced by infiltration of fibrocollagenous tissue which was indeed further strengthens by infiltration of skeletal muscle in the treatment groups. Therefore myoblast seeded scaffolds seems to have superiority over non- seeded scaffolds in cell infiltrations as well as mechanical performances. Similarly Lai et al. (2003) have stated that the success of a tissue-engineered composite might be determined by both the strength of the scaffold and the angiogenesis to support the new cells.

The adhesion formation depends on material surface geometry and affects the correctly organized neo-peritoneum regeneration. In previous in vitro study in which mesothelial cells were seeded onto various biomaterials, it has been established that mesothelialization occurs early when the prosthesis is of laminar type. In contrast, when the biomaterial has the structure of a reticular mesh mesothelial deposition takes place in an irregular manner, with cells settling on the prosthetic filaments, achieving an uneven cover, therefore they speculated that early stage mesothelial deposition after implant is probably conditioned by the structural design of prosthesis (Bello'n et al., 2003).

The origin of adhesions between the organs and the parietal peritoneum has yet to be determined. These formations also appear after biomaterial implantation to repair abdominal wall defect, mainly when macroporous biomaterials, such as polypropylene mesh, are utilized. This fact has been observed by several authors in animal models, such as the Sprague-Dawley rat and the New Zealand white rabbit (Bello'n et al., 1996). Moreover, in human it is well known that intra-peritoneal positioning of conventional parietal mesh provides efficient reconstruction, but it causes visceral adhesion formation in $80-100 \%$ of the cases (Balique et al., 2005). In our study, all the adhesion found between the implanted graft and the visceral organ (caecum) was mild. $33 \%$ and $22.22 \%$ of adhesion was found in control group III and IV respectively. Absence of adhesion in treatment group II was noticed. The early formation of a mesothelium covering the myoblast seeded graft probably explains the lack of adhesion formation observed following implantation. Besides, it is likely that the delay in mesothelialization associated with non-myoblast seeded groups (control) implant gives rise to the frequent adhesions that occur at the biomaterials-visceral peritoneum interface. Ironically, a single case out of nine (11.11\%) rabbits from treatment Group I have showed mild adhesion with caceum which is likely to be affected by the individual variation factors rather than by the type of the implanted grafts (Tables 3 and 4, and Figure 15). 


\begin{tabular}{ccccccc}
\hline \multirow{2}{*}{$\begin{array}{c}\text { Adhesion } \\
\text { degree }\end{array}$} & \multicolumn{6}{c}{ Date of euthanizing } \\
\cline { 2 - 7 } & \multicolumn{3}{c}{ Day } & $7^{\text {th }}$ & \multicolumn{3}{c}{ Day } & 14 $^{\text {th }}$ & \multicolumn{3}{c}{ Day } & $3^{\text {th }}$ \\
\cline { 2 - 7 } & S & C & S & C & S & C \\
\hline 0 & 3 & 2 & 3 & 2 & 2 & 2 \\
1 & 0 & $1^{\star}$ & 0 & $1^{\star}$ & $1^{\star}$ & $1^{\star}$ \\
2 & 0 & 0 & 0 & 0 & 0 & 0 \\
3 & 0 & 0 & 0 & 0 & 0 & 0
\end{tabular}

Based on Mann-Whitney Test, $\mathrm{P}=0.270$, Since $\mathrm{P}>0.05$, there is no significant difference in adhesion formation between treatment and control groups

$S$ - Myoblast seeded BP (Group I)

C - Non seeded BP (group III)

$1^{\star}$ - Showing minimal/ minor adhesion observed between the implanted and the underlying visceral organ

Table 3. Scoring of adhesion formation at $7^{\text {th }}, 14^{\text {th }}$, and $30^{\text {th }}$ days of post-implantation for bovine pericardium scaffolds

\begin{tabular}{|c|c|c|c|c|c|c|}
\hline \multirow{3}{*}{$\begin{array}{c}\text { Adhesion } \\
\text { degree }\end{array}$} & \multicolumn{6}{|c|}{ Date of euthanizing } \\
\hline & \multicolumn{2}{|c|}{ Day 7th } & \multicolumn{2}{|c|}{ Day 14th } & \multicolumn{2}{|c|}{$\overline{D a y}^{30^{\text {th }}}$} \\
\hline & $S$ & $\mathrm{C}$ & $S$ & $\mathrm{C}$ & $S$ & $\mathrm{C}$ \\
\hline 0 & 3 & 2 & 3 & 2 & 3 & 3 \\
\hline 1 & 0 & $1^{*}$ & 0 & $1^{*}$ & 0 & 0 \\
\hline 2 & 0 & 0 & 0 & 0 & 0 & 0 \\
\hline 3 & 0 & 0 & 0 & 0 & 0 & 0 \\
\hline
\end{tabular}

Based on Mann-Whitney Test, $\mathrm{P}=0.145$, Since $\mathrm{P}>0.05$, there is no significant difference in adhesion formation between treatment and control groups.

S - Myoblast seeded BTV (Group II)

C - Non seeded BTV (Group IV)

$1^{*}$ - Showing minimal/ minor adhesion observed between the implant and the underlying visceral organ

Table 4 . Scoring of adhesion formation at $7^{\text {th }}, 14^{\text {th }}$, and $30^{\text {th }}$ days of post-implantation for bovine tunica vaginalis scaffolds

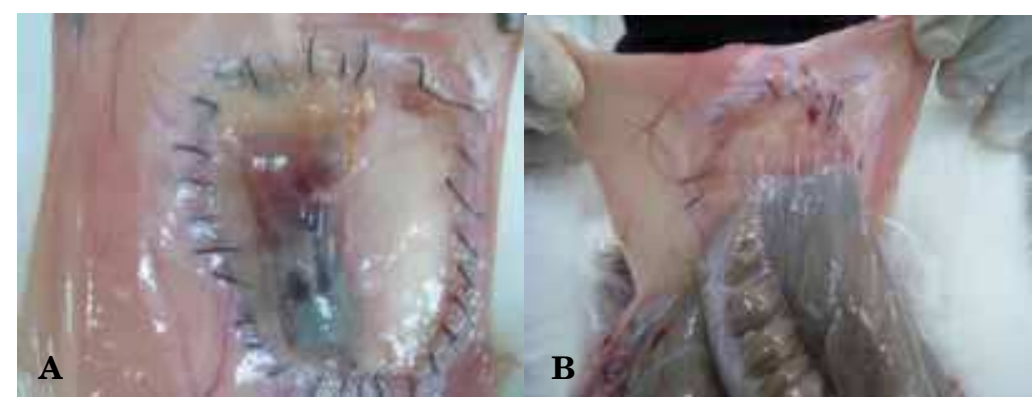

Fig. 15. Peritoneal surface of A) group IV showing seroma formed between neo-peritoneum and the implanted scaffolds at day 7 post-implantation and B) minor adhesion between the implant and caecum at day 14 post-implantation 


\subsection{Light microscopic analysis}

The attack of body immune system on implant can cause failure of the biomaterials to serve as the tissue replacement. Biocompatibility involves the acceptance of biomaterial by the surrounding tissue and by the body as whole (Park \& Lakes, 2007). Histopathologically, the present study revealed that the inflammatory response in all treatment and also controls groups of animals were significantly high during the first week (7th days) of postimplantation (Figure 16). It was indeed an immediate response initiated by surgical trauma when the abdominal well defects were created which perhaps correlated with the inflammatory phase of defects. A similar observations was reported by many researchers (Singh et al., 2008; Zuki et al., 2007; Gangwar et al., 2006; Gamba et al., 2002; Tung et al., 2002).

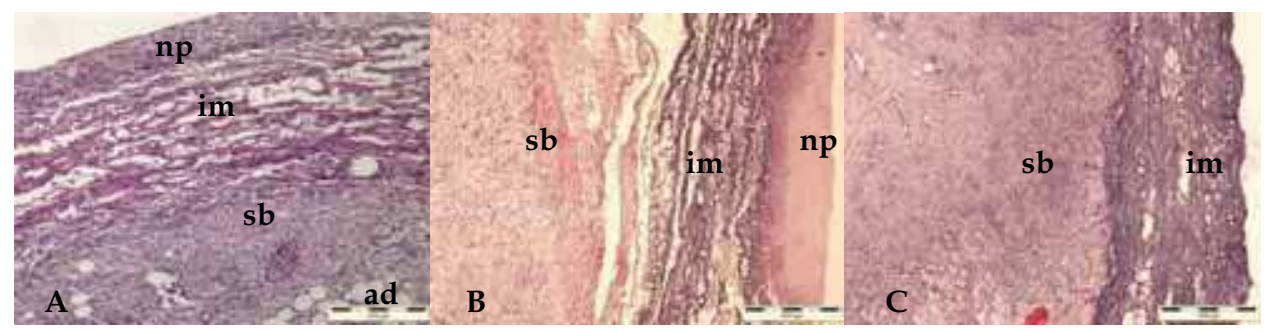

Fig. 16. Microphotographs of group I (A), group II (B) and group IV (C) at 7 th day of postimplantation showing the inflammatory cells surrounding the implanted scaffold (im). Note also the presence of neo-peritoneum (np), subcutaneous tissue (sb) and adiposity (ad) in A and $\mathrm{B}$ but neo-peritoneum was not detected in C. H\&E, Bar $=500 \mu$

Moreover, the inflammatory process is a normal response to surgical injury and the presence of implant as foreign objects. In facts inflammation is necessary as the transitional linking stage between damaged tissue and repair of damaged tissue (Dumitriu, 1994). However, our study showed that the inflammatory process gradually decreased in every advancing period in all treatment and controls groups of both BP and BTV originated scaffolds. These findings suggest that the processing method to produce fibro-collagenous scaffolds is better to removes antigenic proteins and maintain graft integrity. It might also be associated with early degradation and resorption of the implant. As Hafeez (2005) had reported, the cervices and pores created by freeze drying and the fragmentation caused by gamma rays for sterilization in lyophilized grafts enhances inflammatory cells infiltration into the implant and leads to early degradation and resorption. Apart from its processing methods, collagen bundles of the implant in treatment group II and control group IV were not completely resorbed at $30^{\text {th }}$ day of post-implantation, ironically the implant of treatment group I and its control group III has showed better resorption rate. This slight difference might be as a result of higher density of fibro- collagenous nature of BTV originated scaffolds than the BP originated scaffolds.

Previous study that had been reported by Hafeez (2005) indicated that lyophilised BP and BTV graft were started resorption at week three post-implantation in a rat model. However, the present results showed earlier resorption which can be explained by species differences as showed in figure 17. Despite the unknown exact mechanism, several factors, including the animal species, age and site of implantation may play an important role in the rate of degradation of implant (Vialle-Preles et al., 1993). 
This investigation showed that in both control groups (III and IV) the implanted grafts were overwhelmed by fibroblasts, mesenchymal cells and neovascularisation. These mesenchymal and fibroblasts were frequently observed throughout the biomaterials. In fact the collagen fibers and ground substance (matrix) were synthesised and deposited by newly migrating fibroblast as it was showed by the gradual spread of newly formed tissue in the implanted graft. The newly formed collagens in the first week were delicate, immature and unorganized. Later on the $2^{\text {nd }}$ and $4^{\text {th }}$ weeks post-implantation, the amount of collagen fibers increased and infiltrated throughout the implant in well defined and organized form. However, there was not even a single skeletal muscle fiber formation in the implant of control groups. This finding seems consistence with previous reports of biological biomaterials mediated wound repair (Singh et al., 2008; Zuki et al., 2007; Gangwar et al., 2006; Gamba et al., 2002; Tung et al., 2002).

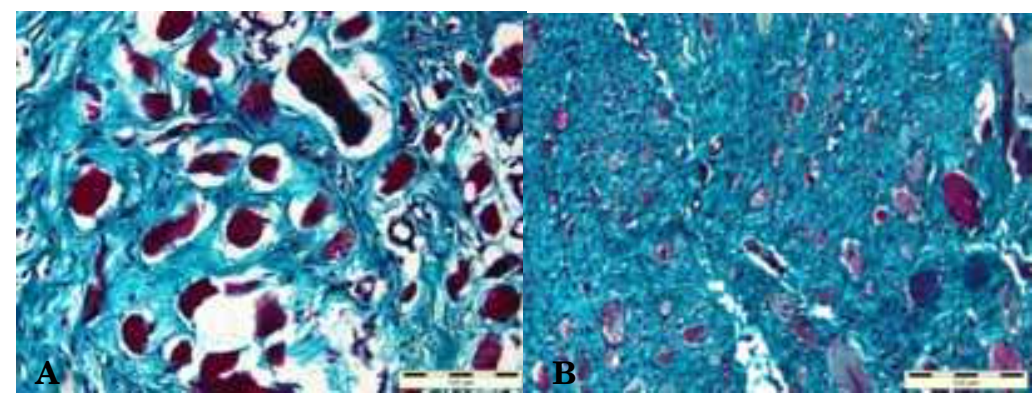

Fig. 17. Microphotographs of group I (A) and group II (B) at $14^{\text {th }}$ day of post-implantation show the graft is completely replaced by collagen fiber (green) and small delicate muscle fibers (red colour). Masson trichrome stain, Bar $=500 \mu$

In contrast to the above cases, in both the treatment groups (I and II), skeletal muscle tissue regeneration were clearly observed. The myoblast were originated from the seeded part, not from the host tissue. At $14^{\text {th }}$ day of post- implantation, the newly formed muscles were young muscle fibers (Figure 17) but eventually at the $4^{\text {th }}$ week post-implantation, they became matured and became well-defined muscle fibers (Figure 18). Since the seeded myoblast were labelled with fluorescence dye and therefore the newly formed muscles fibers were further confirmed by fluorescence microscopy (Figure 19).

The importance of rapid mesotheliazation of biomaterials stems from the fact that adhesion formation is inversely related to the number of mesothelial cells on the peritoneal surface (Law \& Ellis, 1988). Therefore, myoblast seeding on the scaffolds has proved well organized bridging of peritoneal lining (mesotheliazation) across the wound with better vascularisation and this could be contribute to the preventions of intra-abdominal adhesion between the biomaterials and visceral organs.

The formation of foreign body giant cells is a feature of chronic inflammation which occurs in the presence of microorganism or non-phagocytosable materials for long period of time. The foreign body reaction appeared as macrophage and foreign giant cells (Anderson, 1998). In our study absence of foreign body giant cells were noted in both the treatment and control groups of the two types of scaffolds. This could suggest (indicates) the biocompatibility of the scaffolds with the host tissue. Our study has also revealed that both type of myoblast seeded scaffolds showed similar appearance histopathologically, meaning 
that apart from newly formed delicate collagens, newly formed young muscles were observed which eventually became matured and became well-defined muscle fibers. However, on both type of non-myoblast seeded scaffolds (control groups) only delicate, immature and unorganized collagens fibers were observed within the first week which is later on become organized and mature collagens fibers without a single skeletal muscle fibers development.

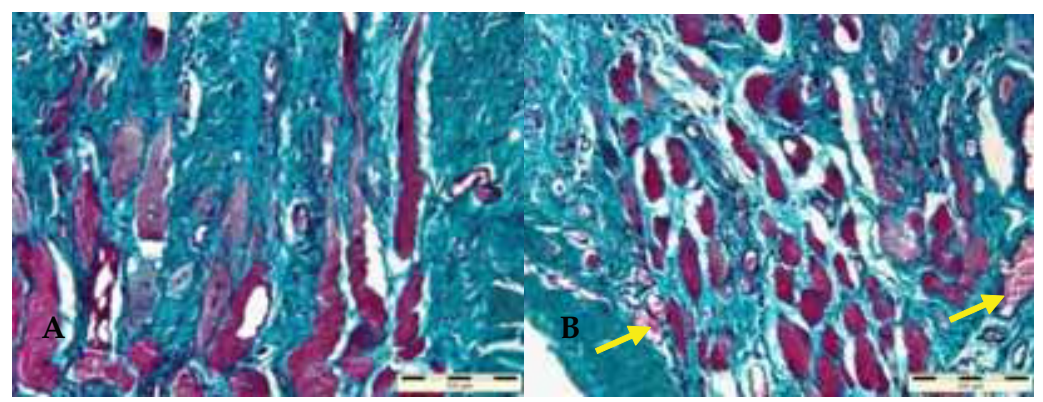

Fig. 18. Microphotographs of Group I (A) and group II (B) at 30th day of post-implantation show the graft was completely replaced by collagen fiber (Green) and well developed muscle fibers (Red) and blood vessels (arrows). Masson trichrome stain, Bar $=100 \mu$

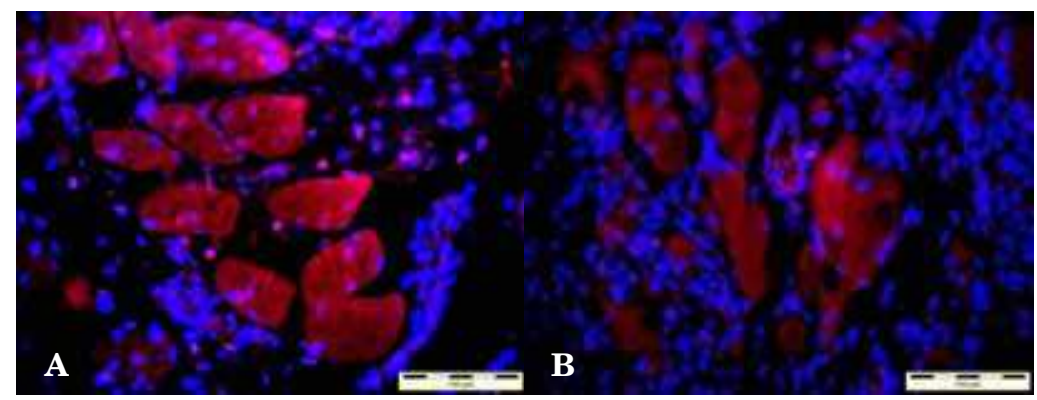

Fig. 19. Double-fluorescence microphotographs of the graph of Group I (A) and group II (B) at day $30^{\text {th }}$ of post-implantation demonstrate the PKH26-labeled myofibers and its DAPIstained nuclei. Note the well developed myotube $/$ myofibers. Bar $=100 \mu$

\subsection{Scanning Electron Microscopic analysis}

The SEM examinations at 7 th day of post-implantation in both I and II revealed infiltration of spherical shape of inflammatory cells with scattered polygonal and spindle shapes of cells on the peritoneal surface indicating the beginning of mesotheliazation as depicted on Figure 20. On day $14^{\text {th }}$ of post-implantation, the treatment groups (I and II) of both type of scaffolds, demonstrated the well organized mesotheliazation with confluent polygonal shapes of cells covering all over the peritoneal surfaces (Figure 21). By day 30th of postimplantation, the treatment groups (I and II) of both type of scaffolds, revealed the well organized mesotheliazation (neo-peritoniazation) where the polygonal shapes of cells covering all over the peritoneal surfaces with numerous cilia like structure (Figure 22). 


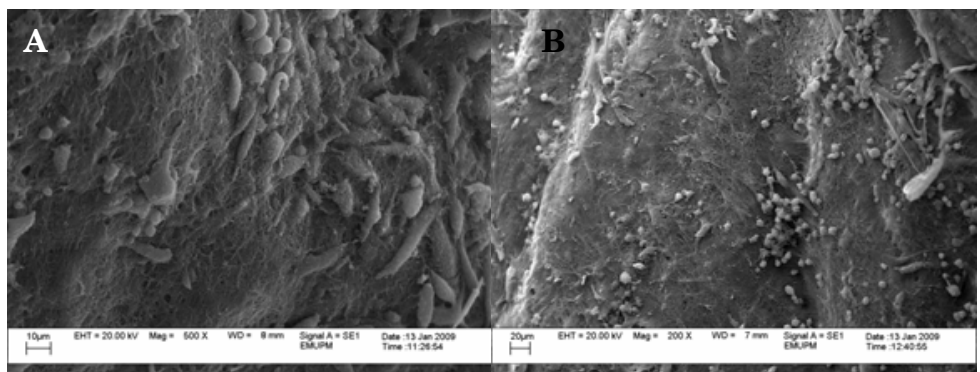

Fig. 20. Scanning electron micrographs of the peritoneal surface of group I (A) and group II (B) on $7^{\text {th }}$ days of post-implantation show the infiltrated spherical shape of inflammatory cells (Yellow arrows) with scattered polygonal and spindle shapes of cells (Red arrows)

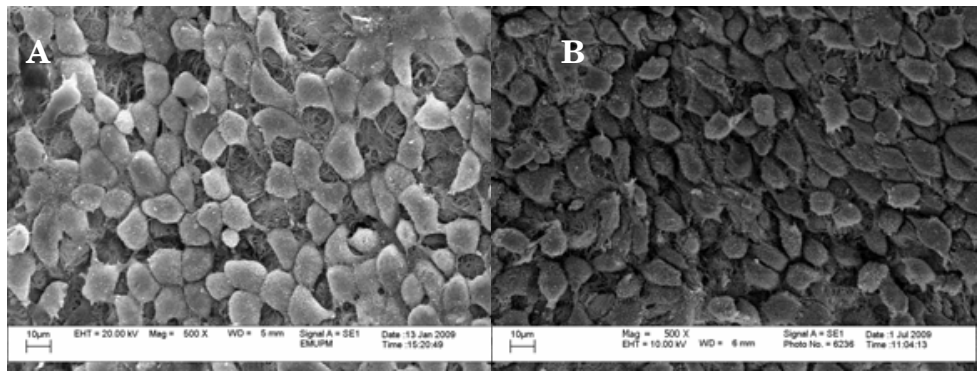

Fig. 21. Scanning electron micrographs of the peritoneal surface of Group I (A) and group II (B) on $14^{\text {th }}$ day of post-implantation show the well organized mesotheliazation of the surface with polygonal shape of mesothelial cells

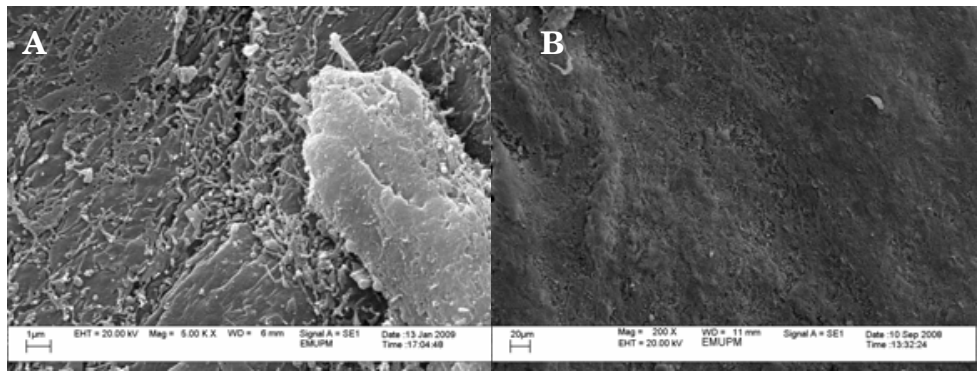

Fig. 22. Scanning electron micrographs of the peritoneal surface of Group I (A) and group II (A) on $30^{\text {th }}$ day of post-implantation show the smooth appearance of the surface with numerous cilia in $\mathrm{A}$

The SEM analysis of the present study has showed a clear understanding by the speed at which mesotheliazation of the myoblast seeded scaffolds in both types of scaffolds on the peritoneal surfaces. These undoubtedly give rise an optimal interface between the graft and visceral organs in avoiding the formation of adhesion and also the appearance of complications related to adhesion because as Chew et al. (2000) had reported in their study 
that firm adhesion may become integrated within the biomaterials which can provoke long term complications such as intestinal fistula in some cases. Moreover, the ultrastructure findings in this study are also indicates reduction of inflammatory cells as the day advances in all the treatment and control groups of both types of scaffolds.

Ultrastructural analysis has further confirmed the profound differences between treatment and its control groups in mesotheliazation/neo-peritoniazation of the peritoneal surfaces. Treatment groups/myoblast seeded scaffolds in both type of scaffolds has showed a well-organized neo-peritoneum generation which might be induced by seeding of myoblast and it could be a good explanation for absence of adhesion. In contrast, on both type of non-myoblast seeded scaffolds (control groups) uneven peritoneum with an irregular mesothelium, which is prone to develop adhesion as reported by Losi et al. (2007).

\subsection{Fluorescence microscopic analysis}

Fluorescence microscopic analysis clearly demonstrates that myoblast seeded biomaterials can be successfully transplanted into artificially created full layer of abdominal wall defects except the skin. The prerequisites for using PKH26 for labelling of cells has been demonstrated in the previous study by many researchers that the incorporation of PKH dye does not physically weaken the membrane of the cells, does not interfere with the functions of the cells and appeared to be ideal for long-term tracking of cells. Animal studies revealed no toxicity of the PKH dye and no immune response appears to generate against labelled cells (Read et al., 1991; Slezak and Horan, 1989a, 1989b; Melnicoff et al., 1988). Most importantly, Johnsson et al. (1997) had reported in their 'ex vivo PKH26-labelling of lymphocytes for studies of cell migration in vivo' study of this labelling dye was found to be retained within the labelled cells and not transferred to other cells.

As expected, the seeded myoblast onto two type of naturally originated collagen based scaffolds materials did not migrate into surrounding tissue rather it remained within the defects. Therefore, cell growth and fusion within the defects suggests that this technique might be suitable for filling volume defects in ectopic locations outside skeletal muscle.

Engineering of multinucleated myotube which later on differentiated into mature striated muscle fibres and its existence for up to the end of the study period showing the superiority of this study to the previous case reported by Van Wachem et al. (1999) where failure of muscle regeneration noted. Lai et al. (2003) has also reported that scaffold covered with skeletal muscle cells did not differ from fibroblast construct in terms of hernia rate. However, Kamelger et al. (2004) have reported the successful regeneration of skeletal muscles in their comparative study of three different biomaterials in the engineering of skeletal muscle using a rat animal model. The fluorescence microscopy have clearly indicated that the similarity of the current results with their study.

In the present study, in both type of myoblast seeded scaffolds the fluorescence microscopy has clearly indicated regeneration of multinucleated skeletal muscle with well developed vascularisation all over the implant and this finding seems consistence with the results reported by Kamelger et al. (2004) and Conconi et al. (2005). However, no PKH26 labelled myoblast was observed in both type of non-myoblast seeded scaffolds, and not even a single skeletal muscle tissue has been detected in the control groups (III and IV), meaning that all the skeletal muscle obtained in the treatment groups were originated from seeding rather from host tissue which indeed confirmed by its PKH26 fluorescence dye. 
Van Wachem et al. (1999) reported one of the reasons for the failure of muscle regeneration may be absence of vascularisation. However, this study has showed that early well vesicularization (neo-angiogenesis) of the implant microscopically and also macroscopically which perhaps may have an impact on the successful regeneration of skeletal muscles at large.

\section{Conclusion}

In general, lyophilized and gamma sterilized BP and BTV scaffolds have showed a tremendous potential for in vitro cultivation of skeletal muscle, it renders great success when used as substrate for filling of wound bed or for the delivery of cells. Myoblast harvested from primary culture are able to proliferate and form myotube in vitro on both type of collagens based biomaterials. This study has also showed that well vascularised biomaterials-myoblast-construct can be successfully implanted for reconstruction of abdominal wall defects which profoundly results in regeneration of skeletal muscle tissue. Myoblast seeded scaffolds did not provoke a significant inflammatory response compared to the non-seeded collagen based scaffold. These engineered myoblast-constructs have better cell infiltration and mechanical performances that ultimately avoid adhesion between the graft and visceral organs than the non-myoblast seeded construct. These finding suggests seeding of myoblast to these scaffolds may be a viable alternative to engineer skeletal muscle tissue for body replacement and remodeling.

\section{Acknowledgement}

The study was supported by e-Science research grant (project no. 06-01-04-SF0203) provided by Malaysian Government.

\section{References}

Amid, K. P. (1997). Classification of biomaterials and their related complications in abdominal wall hernia surgery. Hernia, vol.1, pp. 15-21.

Anderson, J. M. (1988). Inflammatory response to implants. American Society Artificial Internal Organs, vol.34, pp. 101-107.

Badylak, S.; Kokini, K.; Tullius, B.; Simmons-Byrd, A. \& Morff, R. (2002). Morphologic study of small intestinal submucosa as a body wall repair device. eburnal of Surgical Research, vol.103, pp. 190-202.

Badylak, S. F.; Kropp, B. \& McPherson, T. (1998). SIS: A rapidly resorbable bioscaffold for augmentation cystoplasty in a dog model. Tissue Engineering, vol.4, pp. 397-387.

Balique, J. G.; Benchetrit, S.; Bouillot, J. L.; Flament, J. B.; Gouillat , C.; Jarsaillon, P.; Lepère, M.; Mantion, G.; Arnaud, J. P.; Magne, E. \& Brunetti, F. (2005). Intraperitoneal treatment of incisional and umbilical hernias using an innovative composite mesh: four-year results of a prospective multicenter clinical trial. Hernia, vol.9, pp. 68-74.

Bauer, J. J.; Harris, M. T.; Kreel, I. \& Gelernt, I. M. (1999). Twelve-year experience with expanded polytetrafluoroethylene in the repair of abdominal wall defects. Mount Sinai eburnal of Medicine, vol.66, pp. 20-25. 
Bello'n, J. M.; Contreras, L. A.; Buja'n , J. \& Jurado, F. (1996). Effect of phosphatidylcholine on the process of peritoneal adhesion following implantation of a polypropylene mesh prosthesis. Biomaterials, vol.17, pp. 1369-1372.

Bello'n, J. M., Garcia-Honduvilla, N., Lopez, R., Corrales, C., Jurado, F. and Buja'n, J. (2003). In vitro mesothelialization of prosthetic materials designed for the repair of abdominal wall defects. eburnal of Material Science: Material Medicine, vol.14, pp. 35964.

Black, J. (1992). Biological performance of materials, 2nd ed. Marcel Dekker, New York.

Bronzino, J. D. (2006). The Biomedical Engineering Handbook, $3^{\text {rd }}$ ed.CRC Taylor \& Francis Group, LLC. U.S. A.

Calzolari, E.; Bianchi, F.; Dolk, H. \& Milan, M. (1995). Omphalocele and gastroschisis in Europe a survey of 3 million births 1980-1990. American eburnal of Medical Genetics, vol.58, pp. 187-194.

Chang, Y.; Chen, S-C.; Wei, H-J.; Wu, T-J.; Liang, H-C.; Lai, P-H.; Yang, H-H. \& Sung, H-W. (2005). Tissue regeneration observed in a porous acellular BP used to repair a myocardial defect in the right ventricle of a rat model. eburnal of Thoracic and Cardiovascular Surgery, vol.130, pp. 705.e1-e10.

Chang, Y.; Tsai, C-C.; Liang, H-C. \& Sung, H-W. (2002). In vivo evaluation of cellular and acellular bovine pericardia fixed with a naturally occurring crosslinking agent (genipin). Biomaterials, vol.23, pp. 2447-2457.

Chen, J. C. \& Goldhamer, D. J. (2003). Skeletal muscle stem cells. Reproductive Biology and Endocrinology, vol.1, pp. 101-107.

Chew, D. K.; Choi, L. H. \& Rogers, A. M. (2000). Enterocutaneous fistula 14 years after prosthetic mesh repair of a ventral incisional hernia: a life-long risk. Surgery, vol.127, pp. 352-353.

Chung, S.; Hazen, A.; Levine, J. P.; Baux, G.; Olivier, W. A.; Yee, H. T.; Margiotta, M. S.; Karp, N. S. \& Gurtner, G. C. (2003). Vascularized acellular dermal matrix island flaps for the repair of abdominal muscle defects. Plastic and Reconstructive Surgery, vol.111, pp. 225-232.

Clarke, K. L.; Lantz, G. C. \& Salisbury, S. K. (1996). Intestine submucosa and polypropylene mesh for abdominal wall repair in dogs. eburnal of Surgical Research, vol.60, pp. 107114.

Conconi, M. T.; Coppi, P. D.; Bellini, S.; Zara, G.; Sabatti, M.; Marzaro, M.; Zanon, G. F.; Gamba, P. G.; Parnigotto, P. P. \& Nussdorfe, G. G. (2005). Homologous muscle acellular matrix seeded with autologous myoblasts as a tissue-engineering approach to abdominal wall-defect repair. Biomaterials, vol.16, pp. 2567-2574.

Dolgin, S. E.; Midulla, P. \& Shlasko, E. (2000). Unsatisfactory experience with the "minimal intervention management" for gastroschisis. eburnal of Pediatric Surgery, vol.35, pp. 1437-1439.

Drewa, T.; Galazka, P.; Prokurat, A.; Wolski, Z.; Sir, J.; Wysocka, K. \& Czajkowski, R. (2005). Abdominal wall repair using a biodegradable scaffold seeded with cells. eburnal of Pediatric Surgery, vol.40, pp. 317-321.

Dumitriu, S. (1994). Polymeric biomaterials. Marcel Dekker, Inc., pp. 99-108.

Fauza, D. O.; Marler, J. J.; Koka, R.; Forse, R. A.; Mayer, J. E. \& Vacanti, J. P. (2001). Fetal tissue engineering: diaphragmatic replacement. eburnal of Pediatrics Surgery, vol.36, pp. 146-151. 
Gamba, P. G.; Conconi, M. T.; Piccolo, R. L.; Zara, G.; Spinazzi, R. \& Parnigotto, P. P. (2002). Experimental abdominal wall defect repaired with acellular matrix. eburnal of Pediatric Surgery, vol.18, pp. 327-331.

Gangwar, A. K.; Sharma, A. K.; Kumar, N.; Kumar, N.; Maiti, S. K.; Gupta, O. P.; Goswami, T. K. \& Singh, R.(2006). Acellular dermal graft for repair of abdominal wall defects in rabbits. eburnal of the South African Veterinary Association, vol.77, pp. 79-85.

Goddard, J. M. \& Hotchkiss, J. H. (2007). Polymer surface modification for the attachment of bioactive compounds. Progress in Polymer Science, vol.32, pp. 698-725.

Guarita-Souza, L. C.; Carvalho, K. A.; Woitowicz, V.; Rebelatto, C.; Senegaglia, A.; Hansen, P.; Miyague, N.; Francisco, J. C.; Olandoski, M.; Faria-Neto, J. R. \& Brofman, P. (2006). Simultaneous autologous transplantation of cocultured mesenchymal stem cells and skeletal myoblasts improves ventricular function in a murine model of Chagas disease. Circulation, vol.114, pp. I-120-I-124.

Guettier-Sigrist, S.; Coupin, G.; Braun, S.; Warter, J. M. \& Poindron, P. (1998). Muscle could be the therapeutic target in SMA treatment. eburnal of Neuroscience Research, vol.53, pp. 663-669.

Hafeez, Y. M. (2005). Morphological and Biophysical Properties of Bovine Pericardium and Bovine Tunica Vaginalis Xenografts in a Rat Model, PhD. Thesis, University Putra Malaysia.

Hafeez, Y. M.; Zuki, A. B. Z.; Loqman, M. Y.; Noordin, M. M. \& Norimah, Y. (2005b). Comparative evaluations of the processed Bovine Tunica Vaginalis implant in a rat model. Anatomical Science International, vol.80, pp. 181-188.

Hafeez, Y. M.; Zuki, A. B. Z.; Norimah, Y.; Asnah, H.; Loqman, M. Y.; Noordin, M. M. \& Ainul-Yuzairi, M. Y. (2005a). Effect of freeze-drying and gamma irradiation on biomechanical properties of Bovine Pericardium. Cell and Tissue Banking, vol.6, pp. 85-89.

Haider, H. K.; Lei, Y.; Shujia, J. \& Sim, E. K. (2003).Cellular myocardial reconstruction using human myoblasts. eburnal of the American College of Cardiology, vol.42, pp. 589.

Hench, L. L. \& Erthridge, E. C. (1982). Biomaterials: an Interfacial Approach, $1^{\text {st }}$ ed. New York: Academic Press.

Hiles, M. C.; Badylak, S. F. \& Lantz, G. C. (1995). Mechanical properties os xenogeneic small intestinal submucosa when used as an aortic graft in the dog. eburnal of Biomedical Materials Research, vol.29, pp. 883-891.

Huard, J.; Cao, B. \& Qu-Petersen, Z. (2003).Muscle-derived stem cells potential for muscle regeneration. Birth Defects Research Part C, vol.69, pp. 230-237.

Hutmacher, D. W. (2001). Scaffold design and fabrication technologies for engineering tissues-state of the art and future perspectives. eburnal Biomaterial Science, vol.12, pp. 107-124.

James, N. L.; Poole-Warren, L. A.; Schindhlem, B. K.; Mitchell, R. M.; Mitchell, R. E. \& Howlett, C. R. (1991). Comparative evaluation of treated BP as a xenograft for hernia repair. Biomaterial, vol.12, pp. 801-809.

Johnsson, C.; Festin, R.; Tufveson, G. \& Totterman, T. H. (1997). Ex vivo pkh26-labelling of lymphocytes for studies of cell migration In vivo. Scandinavian eburnal of Immunology, vol.45, pp. 511-514. 
Jones, M. L. (2002). Connective tissue and stains. In: Theory and practice of histological techniques, ed. D. J. Bancroft, and M. Gamble, pp.139-162. 5th ed. Churchill Livingstne, New York.

Jose, M.; Garcia, P.; Eduardo, J. H.; Antonio, C.; Isabel, M. A. \& Auroa, R. P. (2001). Ostrich pericardium, a biomaterial for construction of valve leaflets. Biomaterials, vol.22, pp. 2731-2740.

Kamelger, F. S.; Marksteiner, R.; Margreiter, E.; Klima, G.; Wechselberger, G.; Hering, S. \& Piza, H. (2004). A comparative study of three different biomaterials in the engineering of skeletal muscle using a rat animal model. Biomaterials, vol.25, pp. 1649-1655.

Lai, J. Y.; Chang, P. Y. \& Lin, J. N. (2003). Body wall repair using small intestinal submucosa seeded with cells. eburnal of Pediatrics Surgery, vol.38, pp. 1752-1755.

Law, P. K.; Goodwin, T. G.; Fang, Q.; Deering, M. B.; Duggirala, V.; Larkin, C.; Florendo, J. A.; Kirby, D. S.; Li, H. J. \& Chen M. (1993). Cell transplantation as an experimental treatment for Duchenne muscular dystrophy. Cell Transplantation, vol.2, pp. 485505.

Losi , P.; Munao, A.; Spiller , D.; Briganti, E.; Martinelli, I.; Scoccianti, M. \& Soldani, G. (2007). Evaluation of a new composite prosthesis for the repair of abdominal wall defects. eburnal of Material Science: Material Medicine, vol.18, pp. 1939-1944.

Marques, A.; Lopes, A.; Yojo, L.; Brenda, E.; Tulio, M.; Amarante, P. M. \& Torlont, H. (1995). A retrospective study of the use of $\mathrm{BP}$, dura mater, and polypropylene mesh as reinforcement materials in abdominal and thoracic wall reconstruction. Current Therapeutic Research, vol.56, pp. 492-497.

Marzaro, M.; Conconi, M. T.; Perin, L., Giuliani, S.; Gamba, P.; De Coppi, P.; Perrino, G. P.; Parnigotto, P. P. \& Nussdorfer, G. G. (2002). Autologous satellite cell seeding improves in vivo biocompatibility of homologous muscle acellular matrix implants. International eburnal of Molecular Medicine, vol.10, pp. 177-182.

Meddings, R. N.; Carachi, R.; Gorham, S. \& French, D. A. (1993). A new bioprosthesis in large abdominal wall defects. eburnal of Pediatrics Surgery, vol.28, pp. 660-663.

Melnicoff, M. J.; Morahan, P. S.; Jensen, B. D.; Breslin, E. W. \& Horan, P. K. (1988). In vivo labeling of resident peritoneal macrophages. eburnal of Leukocyte Biology, vol.43, pp. 387-397.

Minkes, R. K.; Langer, J. C.; Mazziotti, M. V.; Skinner, M. A. \& Foglia, R. P. (2000). Routine insertion of a silastic spring-loaded silo for infants with gastroschisis. eburnal of Pediatric Surgery, vol.35, pp. 843-846.

MINT Tissue Bank Work Instruction manual (1998). Freeze-drying of tissues and bioburden analysis of tissue products. MTB/WI/016 and MTB/WI/014.

Ott, H. C.; Berjukow, S.; Marksteiner, R.; Margreiter, E.; Bock, G.; Laufer, G. \& Hering, S. (2004). On the fate of skeletal myoblasts in a cardiac environment: down-regulation of voltage-gated ion channels. eburnal of Physiology, vol.558, no.3, pp. 793-805.

Park, J. B. \& Lakes, R. S. (2007). Biomaterials: An In introduction. 3rd ed. Springer Science+Business Media, LLC. pp. 1-16.

Parnigotto, P. P.; Gamba, P. G.; Conconi, M. T. \& Midrio, P. (2000b). Experimental defect in rabbit uretra repaired with acellular aortic matrix. Urological Research, vol.28, pp. 46-51. 
Parnigotto, P. P.; Marzaro, M.; Artusi, T.; Perrino, G. \& Conconi, M. T. (2000a). Short bowel sindrome experimental approach to increase intestinal surface in rats by gastric homologous acellular matrix. eburnal Paediatric Surgery, vol.35, pp. 1304-1308.

Prevel, C. D.; Eppley, B. L. \& Summerlin, D. J. (1995). Small intestinal submucosa: Use in repair of rodent abdominal wall defects. Annals of plastic surgery, vol.35, pp. 374380.

Rando, T. A. \& Blau, H. M. (1994). Primary Mouse Myoblast Purification, Characterization, and Transplantation for Cell-mediated Gene Therapy. eburnal of Cell Biology, vol.125, pp. 1275-1287.

Read, E. J.; Cardine, L. L. \& Yu, M. Y. (1991). Flowcytometric detection of human red cells labelled with a fluorescent membrane label: potential appealication to in vivo survival studies. Transfusion, vol.31, pp. 502-508.

Rodgers, B. M.; Maher, J. M. \& Talber, N. (1981). The use of preserved human dura for closure of abdominal and diaphragmatic defects. Annual of surgery, vol.193, pp. 606611.

Roeder, R.; Wolfe, J.; Lianakis, N.; Hinson, T.; Geddes, L. A. \& Obermiller, J. (1999). Compliance, elastic modulus, and burst pressure of small-intestine submucosa (SIS), small-diameter vascular grafts. eburnal of Biomedical Materials Research, vol.47, pp. 65-70.

Saaverda, S.; Pelaaez, M. D.; Alvarez Zapico, J. A.; Gutierrez, S. C. \& Fernandez, J. (2001). Fascia lata transplant from cadavric donor in the reconstruction of abdominal wall defects in children. Cirugia Pediatrica, vol.14, pp. 28-30.

Santillan, D. P.; Jasso, V. R.; Sotres-Vega, A.; Olmos, R.; Arreola, J. L.; Garc-ia, D.; Vanda, B. \& Gaxiola, M (1995). Repair of thoraco-abdominal wall defects in dogs using a BP bioprosthesis. Revista de investigation Clinica, Organo Del Hospital De Enfermedades De LaNutricion, vol.47, pp. 439-446.

Saxena, A. K. (2005). Tissue engineering: Present concepts and strategies. eburnal of Indian Association of Pediatric Surgeons, vol.10, pp. 14-19.

Saxena, A. K. \& Willital, G. H. (2000). Skeletal muscle tissue-engineering. International Medical eburnal of Experimental \& Clinical Research, vol.6, pp. 18.

Saxena, A. K.; Marler, J.; Benvenuto, M.; Willital, G. H. \& Vacanti, J. P. (1999b). Skeletal muscle tissue engineering using isolated myoblasts on synthetic biodegradable polymers: preliminary studies. Tissue Engineering, vol.5, pp. 525-532.

Saxena, A. K.; Willital, G. H. \& Vacanti, J. P. (2001). Vascularized three-dimensional skeletal muscle tissue-engineering. Bio-Medical Materials and Engineering, vol.11, pp. 275-281.

Saxena, A. K.; pcker, H. \& Willital, G. H. (1999a). Present status of tissue engineering for surgical indications in children. $116^{\text {th }}$ Congress of the German Association for Surgery, Munich, Germany.

Schlatter, M.; Norris, K.; Uitvlugt, N.; DeCou, J. \& Connors, R. (2003). Improved outcomes in the treatment of gastroschisis using a preformed silo and delayed repair approach. cburnal of Pediatric Surgery, vol.38, pp. 459-464.

Silver, I. A. (1982). Basic physiology of wound healing in horse. Equine Veterinary eburnal, vol.14, pp. 7-15.

Singh, J.; Kumar, N.; Sharma, A. K.; Maiti, S. K.; Goswami, T. K. \& Sharma, A. K. (2008). Acellular Biomaterials of Porcine Origin for the Reconstruction of Abdominal Wall Defects in Rabbits. Trends in Biomaterials \& Artificial Organs, vol.22, pp. 0-0. 
Skalak, R. \& Fox, C. F. (1988). Tissue Engineering: Proceedings of a workshop held at Granlibakken, Lake Tahoe, CA, New York, NY: Liss. pp. 26-29.

Slezak, S. E. \& Horan, P. K. (1989a). Cell-mediated cytotoxicity. A highly sensitive and informative flow cytometric assay. eburnal of Immunological Methods, vol.117, pp. 205-214.

Slezak, S. E. \& Horan, P. K. (1989b). Fluorescent in vivo tracking of hematopoietic cells. Part I. Technical consideration. Blood, vol.74, pp. 2172-2177.

Smith, S.; Gantt, N.; Rowe, M. I. \& Lloyd, D. A. (1989). Dura versus goretex as an abdominal wall prosthesis in an open and closed infected model. eburnal of Pediatric Surgery, vol.24, pp. 519-521.

Sutherland, R. S.; Baskin, L. S.; Hayward, S.W. \& Cunha, G.R. (1996). Regeneration of bladder urothelium, smooth muscle, blood vessels and nerves into an acellular tissue matrix. eburnal of Urology, vol.156, pp. 571-577.

Tung, W. S.; Zainol, J.; Pilly, A. G.; Yusof, N. \& Yusof, L. M. (2002). Processed BTV as a Biomaterial for the Repair of Large Abdominal Wall Defects in Surgical Treatment. The Science, vol.2, pp. 7-11.

Tyrell, J.; Silberman, H.; Chandrasoma, P.; Niland, J. \& Shull, J. (1989). Absorbable versus permanent mesh in abdominal operations. Surgery, Gynecology and Obstetrics, vol.168, pp. 227-232.

Ueno, T.; Pickett, L. C.; La Fuente, S. G.; Lawson, C. \& Pappas, T. N. (2004). Clinical application of porcine small intestine submucosa in the management of infected or potentially contaminated abdominal defects. eburnal of Gastrointestinal Surgery, vol.8, pp. 109-112.

Van Wachem, P. B.; Brouwer, L. A. \& van Luyn, M. J. A. (1999). Absence of muscle regeneration after implantation of a collagen matrix seeded with myoblasts. Biomaterials, vol.20, pp. 419-426.

Vialle-Preles, M. J.; Hartmann, D. J.; Franc, S. \& Herbage, D. (1993). Imminuhistochemistry study of the biological fate of a subcutaneous bovine collagen implant in rat. Histochemistry, vol.91, pp. 177-184.

Wei, C. Y.; Chuang, D. C.; Chen, H. C.; Lin, C. H.; Wong, S. S. \& Wei, F. C. (1995). The versatility of free rectus femoris muscle flap an alternative flap. Microsurgery, vol.16, pp. 698-703.

Wernig, A.; Zweyer, M. \& Irintchev, A. (2000). Function of skeletal muscle tissue formed after myoblast transplantation into irradiated mouse muscles. cburnal of Physiology, vol.522, pp. 333-345.

Wilson, L. \& Gamble, M. (2002). The hematoxylins and eosin. In:Theory and practice of histological techniques, ed. D. J. Bancroft, and M. Gamble, pp.125-138. 5th ed. Churchill Livingstne, New York.

Winokur, S. T.; Barrett, K.; Martin, J. H.; Forrester, J. R.; Simon, M.; Tawil, R.; Chung, S-A.; Masny, P. S \& Figlewicz, D. A. (2003). Facioscapulohumeral muscular dystrophy (FSHD) myoblasts demonstrate increased susceptibility to oxidative stress. Neuromuscular Disorders, vol.13, pp. 322-333.

Won, K. L.; Ki, D. P.; Dong, K. H.; Hwal, S.; Jong-Chul, P. \& Young, H. K. (2000). Heparinized BP as a novel cardiovascular bioprosthesis. Biomaterials, vol.2, pp. 2323-2330. 
Wu, D.; Razzano, P. \& Grande, D. A. (2003). Gene therapy and tissue engineering in repair of the musculoskeletal system. eburnal of Cellular Biochemistry, vol.88, pp. 467-481.

Yan, W.; Fotadar, U.; George, S.; Yost, M.; Price, R. \& Terracio, L. (2006). Tissue engineering of skeletal muscle. Microscopy and Microanalysis, vol.11, pp. 1254-1255.

Zuki, A. B. Z.; Hafeez, Y. M.; Loqman, M. Y.; Noordin, M. M. \& Norimah, Y. (2007). Effect of Preservation Methods on the Performance of Bovine Pericardium Grafts in a Rat Model. Anatomia Histologia Embryologia, vol.36, pp. 349-356. 


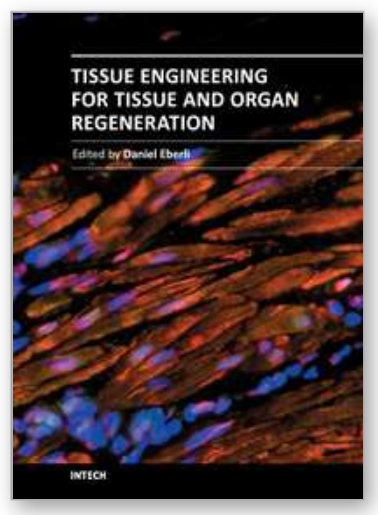

\author{
Tissue Engineering for Tissue and Organ Regeneration \\ Edited by Prof. Daniel Eberli
}

ISBN 978-953-307-688-1

Hard cover, 454 pages

Publisher InTech

Published online 17, August, 2011

Published in print edition August, 2011

Tissue Engineering may offer new treatment alternatives for organ replacement or repair deteriorated organs. Among the clinical applications of Tissue Engineering are the production of artificial skin for burn patients, tissue engineered trachea, cartilage for knee-replacement procedures, urinary bladder replacement, urethra substitutes and cellular therapies for the treatment of urinary incontinence. The Tissue Engineering approach has major advantages over traditional organ transplantation and circumvents the problem of organ shortage. Tissues reconstructed from readily available biopsy material induce only minimal or no immunogenicity when reimplanted in the patient. This book is aimed at anyone interested in the application of Tissue Engineering in different organ systems. It offers insights into a wide variety of strategies applying the principles of Tissue Engineering to tissue and organ regeneration.

\title{
How to reference
}

In order to correctly reference this scholarly work, feel free to copy and paste the following:

Zuki Abu Bakar, Ayele Taddese Tsedeke, Noorjahan Banu Mohamed Alitheen and Noordin Mohamed Mustapha (2011). Skeletal Muscle Tissue Engineering Using Biological Scaffolds for Repair of Abdominal Wall Defects in a Rabbit Model, Tissue Engineering for Tissue and Organ Regeneration, Prof. Daniel Eberli (Ed.), ISBN: 978-953-307-688-1, InTech, Available from: http://www.intechopen.com/books/tissue-engineering-fortissue-and-organ-regeneration/skeletal-muscle-tissue-engineering-using-biological-scaffolds-for-repair-ofabdominal-wall-defects- $i$

\section{INTECH}

open science | open minds

\section{InTech Europe}

University Campus STeP Ri

Slavka Krautzeka 83/A

51000 Rijeka, Croatia

Phone: +385 (51) 770447

Fax: +385 (51) 686166

www.intechopen.com

\section{InTech China}

Unit 405, Office Block, Hotel Equatorial Shanghai

No.65, Yan An Road (West), Shanghai, 200040, China

中国上海市延安西路65号上海国际贵都大饭店办公楼405单元

Phone: +86-21-62489820

Fax: +86-21-62489821 
(C) 2011 The Author(s). Licensee IntechOpen. This chapter is distributed under the terms of the Creative Commons Attribution-NonCommercialShareAlike-3.0 License, which permits use, distribution and reproduction for non-commercial purposes, provided the original is properly cited and derivative works building on this content are distributed under the same license. 